\title{
Framing the solution to the problem of coal seam state by the methods of the mechanics of granular materials
}

\author{
Nikolai V. Cherdantsev ${ }^{1}$ \\ ${ }^{1}$ Federal Research Center of Coal and Coal Chemistry SB RAS, Kemerovo, Russia \\ e-mail: nvch2014@yandex.ru
}

\begin{abstract}
Introduction. It is essential to reliably estimate the geomechanical state of marginal zones at a mineable coal seam in order to ensure mining balance and safety.

Research aim is to build the model of the state of a coal seam in its marginal zone based on the fundamental methods of the mechanics of granular materials, make calculations within the framework of the model, analyze the results and compare them with the results obtained by the well-known methods. Methodology. The problem of the stressed state of coal seam marginal zones is implemented by means of numerical solution of three boundary value problems of limit equilibrium theory for a range of typical areas situated in these zones. The criterion of limit state beginning is concurrent compliance with Coulomb-Mohr stratum condition and Mohr-Kuznetsov condition along the contact with rock wall.

Results. It has been shown that the components of stress field change non-monotonically along the seam roof. Sections with constant stresses are changed by sections with stresses nonlinear increase. With distance from the marginal part into the depth of the massif, the size of sections with constant stresses decreases. The obtained stress results have been compared with the results obtained with the use of voltage change exponential formula. The dimensions of seam marginal zone have been determined with rather close results of two approaches.

Summary. Polynomial approximation of the obtained graphs allows accurately replace the results of numerical solution to the limit state problem by analytical functions and simplify the solution to the problem of the enclosing rock stressed state.
\end{abstract}

Key words: rock mass; coal seam; mine; limit stress seam zones; Coulomb-Mohr and MohrKuznetsov strength criteria.

Introduction. Evaluation of stress-strain state of the rock mass enclosing a coal seam and the mine working within it is an important and relevant scientific problem. The presence of the limit stress zones in seam marginal parts cause various geodynamic events: rockbursts, rock mass outbursts from mine faces, soil heave, and significant roof displacement [1-8].

Data on seam limit stress state in the marginal zone is essential in order to forecast the estimates of geodynamic effects. It is evident that results obtained as early as at the stage of mining enterprise design and before mining are important as soon as they make it possible to avoid expensive field experiments. Physical-mathematical simulations based on the main provisions, principles and methods of deformable solid mechanics and taking into account the fullest data on the environment under investigation $[5,9-16]$ can provide reliable results and forecast estimates of the geomechanical state of massifs.

From this point of view, G. L. Firsenko approach, based on the V. V. Sokolovsky fundamental methods for granular materials calculation [12], clearly reflects stressstrain state of a coal-bearing mass. Results obtained within the simulation developed by 
G. L. Firsenko are in good agreement with the results of field experiments with the approach successfully applied by researches [13-15] in order to estimate the geomechanical state of a coal seam and its soft rock and in the vicinity of the geological disturbance.

A bearing pressure curve is defined approximately in the form of an exponential function, and this is the main disadvantage. It makes it possible to avoid solving nonlinear differential equations of media limit state, but it does not estimate the accuracy of the solution as soon as there was no complete solution to nonlinear equations of the limit state.

The present research states the following tasks. Firstly, calculate seam marginal zone by numerical integration of the limit-state differential equations. Secondly, fulfill the comparative analysis of the calculation results and the results obtained by G. L. Firsenko approach, and ascertain validity limits of the latter.

Problem statement and its solution. In the rock mass simulated by a weightless plane there is a mine working with a rectangular cross section $b \times h$ in size at the depth of $H$ through the coal seam with $m$ thickness. Coal seam strength characteristic: $C$ - the cohesion coefficient, $\rho$ - the angle of shear resistance; they are much less than rock strength characteristic of the main mass, but they exceed the cohesion coefficient $C^{\prime}$ and the angle of shear resistance $\rho^{\prime}$ at seam contacts with the remaining mass. Coordinate system $y 0 z$ is tied to the middle of the seam edge. It is believed that digging is fulfilled at the depth which causes limit stress (plastic) zones generate at seam marginal parts. The aim of solution to the problem is to obtain quantitative and qualitative results of stresses distribution in seam marginal zone.

Simultaneous survey of general and special conditions of the limit state allows obtaining a formula for an angle between the contact between the mass and the friction plane in a coal seam in the points at this contact $[5,10]$

$$
\theta=\frac{\pi}{4}+\frac{1}{2}\left(\rho-\rho^{\prime}\right)-\frac{1}{2} \arcsin \left[\frac{\sin \rho^{\prime}}{\sin \rho}\left(1-\frac{c}{\sigma}\right)\right],
$$

where $\sigma-$ mean adjusted stress; $\sigma$ and the parameter $c$ are determined by the formula

$$
\sigma=c+\frac{\sigma_{1}+\sigma_{3}}{2}, \quad c=C \operatorname{ctg} \rho=\frac{(1-\sin \rho)}{2 \sin \rho} \sigma_{0},
$$

$\sigma_{0}-$ compressive strength of a seam.

It is obvious that there is only vertical main stress $\sigma_{1}$, equal to $\sigma_{0}$, which acts at coal seam uncovering, while main stress $\sigma_{3}$ is equal to zero. Formula (1), after substituting formulae (2) into it, accepting that $\sigma_{1}=\sigma_{0}, \sigma_{3}=0$, takes the form

$$
\theta=\frac{\pi}{4}+\frac{\rho}{2}-\rho^{\prime}
$$

Evaluation of the limit state of the seam itself is reduced to the solution of two differential equations obtained by means of substituting the criterion of Coulomb-Mohr limit state into the system of differential equation of equilibrium, complying with the conditions at the edges of the area.

The obtained system of equations is nonlinear and refers to hyperbolic equations. In this system, mean adjusted stress $\sigma$ and angle $\varphi$ between the direction of the main stress $\sigma_{1}$ and $y$ axis are unknown. 
Main stresses $\sigma_{1}$ and $\sigma_{3}$ are tied with $\sigma$ and angle $\varphi$ by the following ratios $[5,10,12]$ :

$$
\begin{gathered}
\sigma_{y}=\sigma[1+\sin (\rho) \cos (2 \varphi)]-c \\
\sigma_{z}=\sigma[1-\sin (\rho) \cos (2 \varphi)]-c \\
\tau_{y z}=\sigma \sin (\rho) \sin (2 \varphi)-c .
\end{gathered}
$$

When solving hyperbolic equations, a method of characteristics (characteristic curves) is used, significantly simplifying differential equations. They physically coincide with glide lines - directed lines in the medium where lateral faulting is maximum [12].

Despite the fact that at glide lines the system of equation simplifies, in general, it is integrated only numerically, its solution reducing to some table completion with the use of recurrent relations obtained at differential relations substitution for their finitedifference expressions [12].

Depending on boundary conditions there are three boundary value problems of limit state.

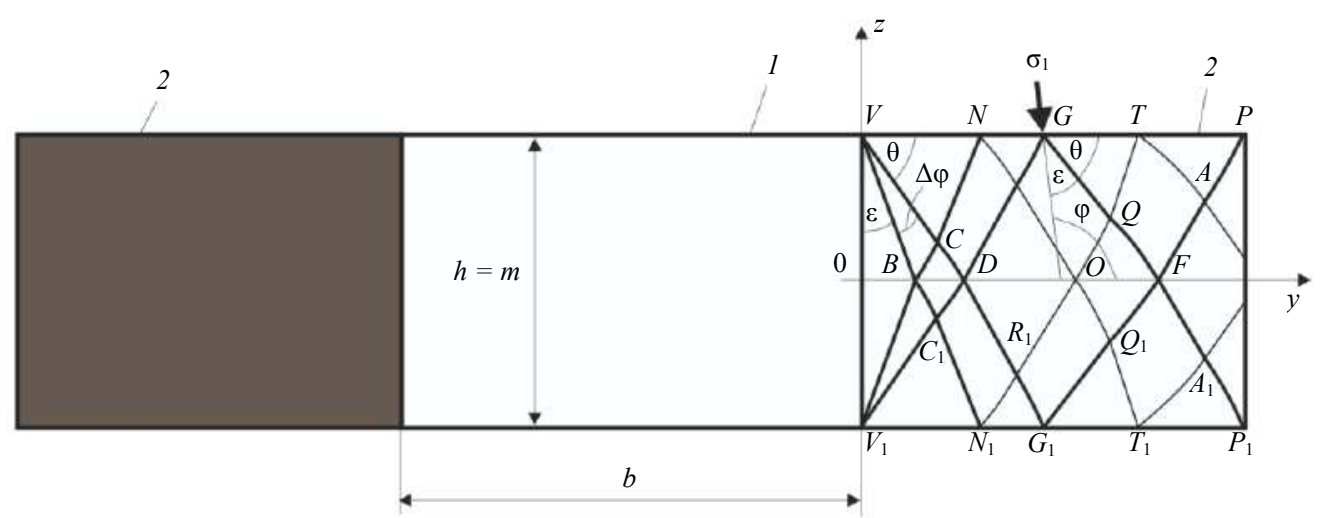

Fig. 1. The scheme of a mine working and limit stress zones in a coal seam: 1 - mine working, 2 - limit stress zones of a seam

Рис. 1. Схема выработки и предельно напряженных зон в угольном пласте: 1 - выработка, 2 - предельно напряженные зоны пласта

At the first boundary value problem, there are point coordinates $y, z$ specified at the boundary of the area, as well as stress $\sigma$ and angle $\varphi$. According to these values and recurrent ratios, a slip-line network is built, and $\sigma, \varphi$ in its nodes are determined.

At the second boundary value problem, boundary conditions are specified at two boundaries of the area, and its solution, just like at the first boundary value problem, is carried out in accordance with the recurrent relations.

At the third boundary value problem, there are coordinates of glide line of one family and values $\sigma$ and $\varphi$ specified at one boundary. At the other boundary, two finite or differential relations between the coordinates of the second system of glide lines are known, as well as $\sigma$ or $\varphi$, belonging to other system of glide lines. The development of a slip-line network and other values calculation is carried out by the same recurrent formulae.

If boundary conditions in the first and second boundary value problems are simple enough, for example, $\sigma$ is constant, then they can be solved in closed (analytical) form:

So, for example, at the uncovering of the seam, the following boundary conditions are specified $-h / 2 \leq z \leq h / 2 ; y=0 ; \sigma_{1}=\sigma_{0} ; \sigma_{3}=0 ; \varphi=90^{\circ}$. Consequently, the problem 
is a boundary value problem. The solution to the problem is quite simple. It is rather evident that glide lines of this area make up the network of isogonal lines which deviate from the vertical line to the angle of $\pm \varepsilon$ (fig. 1), and the section itself represents the triangle prism $V B V_{1}$, where stresses are constant and equal to the stresses at the boundary.

Sections adjoining $V B V_{1}$ area represent two symmetrical triangle prisms, $V C B$ and $V_{1} C_{1} B_{1}$, they are called Prandtl zones. The problem of building up a stress field in Prandtl zones refers to the second boundary value problem, and the solution can also be represented in a closed form. Glide lines within them consist of a cone of rays going out of the angular pints $V$ and $V_{1}$, and logarithmic spirals. Stresses along the radial glide lines are constant, while stresses along the logarithmic spirals change exponentially.

In $V C N\left(V_{1} C_{1} N_{1}\right)$ area situated between two rectilinear boundaries, $V N$ and $V N_{1}$, the third boundary value problem is solved. As soon as the boundaries are rectilinear, the solution is closed and simple: a network of glide lines consists of two systems of isogonal lines with constant stresses.

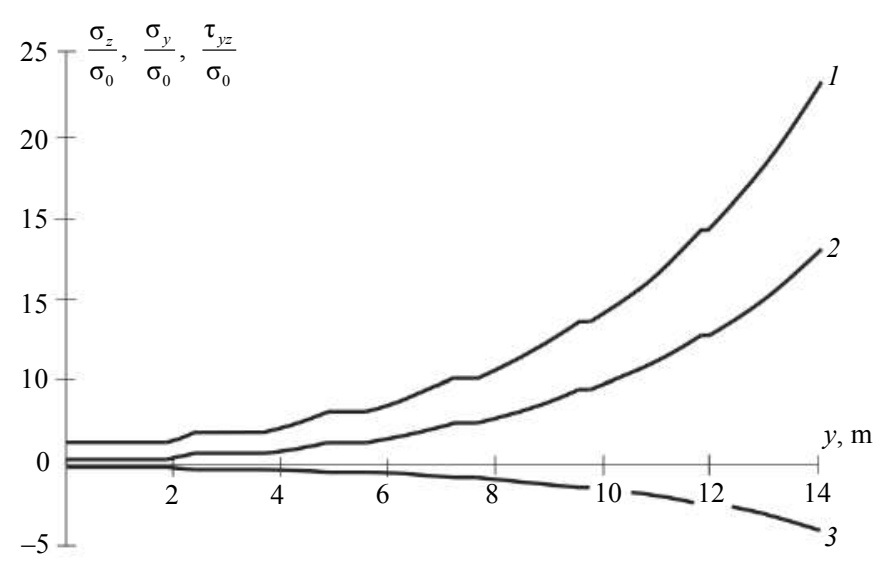

Fig. 2. Curves of stresses along the seam roof

Рис. 2. Эпюры напряжений вдоль кровли пласта

In a curvilinear rectangle $B C D C_{1}$ the problem is the second boundary value problem and is solved in a closed form with a network of glide lines consisting of logarithmic spirals along which stresses change exponentially.

In symmetrical sectors $C D R N$ and $C_{1} D R_{1} N_{1}$, the problem is referred to the second boundary value problem and has a closed solution. Glide lines along $\mathrm{CN}$ and $D R$ boundaries consist of the radial line segments each possessing constant stresses. Along curvilinear segments $C N$ and $D R$ glide lines are logarithmic spirals where stresses change exponentially.

In triangle sections $N R G$ and $N_{1} R_{1} G_{1}$ the system of differential equations is no longer integrated in a closed form. In this case, it is solved numerically and refers to the third boundary value problem of limit state. At a line $N R$, boundary conditions are known, as soon as it is a junction line at $C D R N$ area; at $N G$ boundary, the coordinates of each point and the value of an undulating gradient $\varphi$ are known, being easily determined from fig. 1 by formula

$$
\varphi=\pi-(\theta+\varepsilon)=\frac{\pi}{2}+\frac{1}{2} \rho^{\prime}+\frac{1}{2} \arcsin \left[\frac{\sin \rho^{\prime}}{\sin \rho}\left(1-\frac{c}{\sigma}\right)\right] .
$$


Thereby, areas $V C D R_{1} G_{1} N_{1} C_{1} B$ and $V_{1} C_{1} D R G N C B$ as sectors represent the aggregate of sections with individual features of glide lines and stresses distribution in each section.

These areas border on the other rectangular area $D G_{1} F G$ along $D G$ and $D G_{1}$ lines. Being nonuniform in the areas of the sectors, the network of glide lines is also nonuniform in $D G_{1} F G$ area. Boundary line $D G$ actually consists of the rectilinear segment $D R$ and a curvilinear segment $R G$. It follows from above that inside of $D R O R_{1}$ with rectilinear boundaries $D R$ and $D R_{1}$ within $D G_{1} F G$ area under consideration, the network of glide lines consists of the isogonal lines, and stresses in its nodes are constant everywhere.

$R G$ boundary of $R G Q O$ section, which is another section of the upper half of the given area, is curvilinear, and $R O$ boundary is rectilinear. It follows from above that glide lines within the section consist of rectilinear and curvilinear segments. Stresses are constant along the straight lines, and alternating along the curvilinear segments. Within $O Q F Q_{1}$ section of the same area, the network of glide lines will be curvilinear, as soon as boundaries $O Q$ and $O Q_{1}$ of the section are curvilinear. Therefore, stresses within the section are alternating.

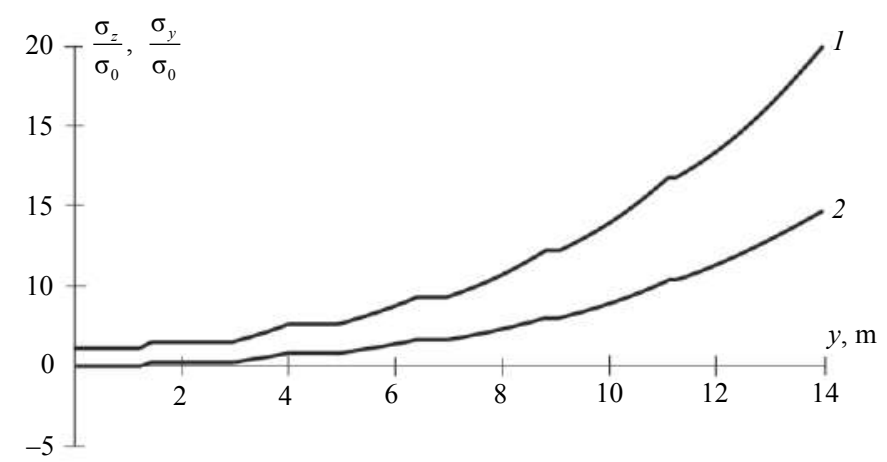

Fig. 3. Curves of stresses along the midline of a seam Рис. 3. Эпюры напряжений вдоль средней линии пласта

The character of glide lines and stresses distribution in FGP area and the symmetrical $F G_{1} P_{1}$ area is possible to be determined in the same manner. Thus, at section $G T Q$ of this area, the network of glide lines is isogonal, and stresses are constant. At QTAF section, the network of glide lines consists of rectilinear and curvilinear sections with alternating stresses. At ATP section, the network of glide lines is curvilinear, it means that the stresses within are alternating.

The speculations above result in the conclusion on the character of stresses distribution along the mid-seam (along $y$ axis) and along the seam roof ( $V P$ line). So, for instance, along $O B, D O, V N, G T$ segments the stresses are constant, and along $B D, O F, N G, T P$ segments they are alternating.

Problem solution results and their analysis. Here're the results of solving the problem of seam marginal part limit state. The results are obtained in the course of numerical solution of boundary value problems of limit state theory in a number of typical areas of seam marginal zone. The following parameters of a massif and a seam are accepted as source information: $\sigma_{0}=10 \mathrm{MPa} ; \rho=20^{\circ} ; C^{\prime}=0 ; \rho^{\prime}=10^{\circ} ; h=m=3 \mathrm{~m}$.

Fig. 2 shows distribution graphs (curves) of normal stress $\sigma_{z}$ (curve 1 ), $\sigma_{y}$ (curve 2) and shear stresses $\tau_{y z}$ (curve 3) along the seam roof. They are built based on ratios (3), where $\sigma$ and $\varphi$ are determined during boundary value problems solution for the areas of the limit stress zone. 
The character of changes in stress curves proves the earlier speculations on stresses behaviour in the areas and at the sections of seam limit stress zone. Stresses along the roof actually do not change steadily. Sections with constant stress interchange with sections with nonlinear buildup of stress, and with distance from the edge of the seam, the intensity of stresses buildup grows, and the length of sections with constant stresses reduces. Curves are built according to the results of boundary value problems for eight areas, the length of the limit stress zone being $14 \mathrm{~m}$.

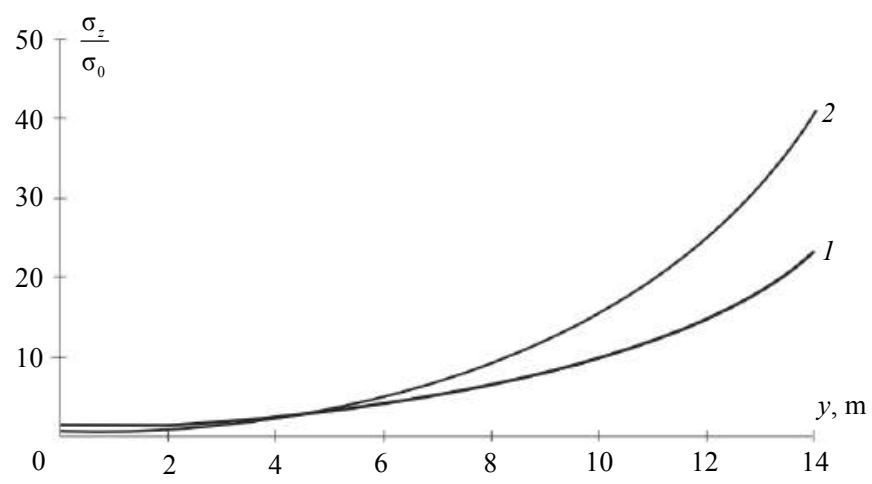

Fig. 4. Curves of $\sigma_{z}$ stresses along the seam roof by two approaches

Рис. 4. Эпюры напряжений $\sigma_{z}$ вдоль кровли пласта по двум подходам

Fig. 3 shows the graphs of normal stresses $\sigma_{z}$ (curve 1 ), $\sigma_{y}$ (curve 2) along the midseam, which coincides with axis $y$. Shear stresses are absent as soon as at the symmetry axis shear stresses are equal to zero. It follows from fig. 3 that the values of stresses along the mid-seam are insignificant, but they are lower than the values of stresses along the roof of the seam at fig. 2 .

When solving the elastoplastic problem, the use of the stress curves which have been obtained directly will result in the more complicated formulation of boundary conditions as compared to the analytical functions.

The obtained stress curves are approximated by the polynomials where the number of members is equal to the number of typical sections of the limit stress zone. In order to determine the coefficients of each polynomial, the system of algebraic equations is solved with the number equal to the number of the sections, equations right parts corresponding to the values of the determined stresses at the margins of the sections.

Fig. 4 presents two curves of vertical stresses distribution. Curve 1 - a polynomial which approximates stresses $\sigma_{z}$, curve 2 is built by formulae (3) for $\sigma_{z}$, where the reduced stress $\sigma$ is determined by G. L. Fisenko exponential dependence [5]

$$
\sigma=\frac{\sigma_{0}}{2 \sin \rho} e^{k y}, \quad \text { where } k=\frac{2}{m} \cdot \frac{1+\sin \rho}{1-\sin \rho} \operatorname{tg} \rho^{\prime}
$$

It follows from the analysis of fig. 4 that the curve ordinates are close to each other within the limit stress section of about $4 \mathrm{~m}$ length. With a greater length of the section the difference in the ordinates grows, and with $14 \mathrm{~m}(4.44 \mathrm{~m})$ long limit zone it is about $76.5 \%$. 
Summary. A rigorous solution to the problem of seam limit stress zone calculation by the methods of the mechanics of granular materials. The solution consists in the successive numerical solution of nonlinear differential equations of limit state boundary problems for a range of typical areas in this zone.

The graphs of normal stresses distribution along the seam roof, which have been built in the course of the problem solution, represent the aggregate of sections; sections with constant stresses are changed by sections with nonlinear increase. With the growth of abscissa, the length of the sections with constant stress reduces, and the intensity of stress growth at the sections of their nonlinear growth rises sharply.

Graphs of stress distribution in seam limit stress zone, obtained through the proposed solution, are close enough to the graphs built by G. L. Fisenko exponential formula, only a small section having zones not more than one third of the seam height size. At the distance from the seam edge of four and a half seam heights, the difference between the results is significant and exceeds $75 \%$.

\section{REFERENCES}

1. Petukhov I. M., Linkov A. M. The mechanics of rockbursts and outbursts. Moscow: Nedra Publishing; 1983. (In Russ.)

2. Chernov O. I., Puzyrev V. N. The forecast of coal and gas outbursts. Moscow: Nedra Publishing; 1979. (In Russ.)

3. Zhang C., Canbulat I., Tahmasebinia F., Hebblewhite B. Assessment of energy release mechanisms contributing to coal burst. Int. J. Rock Min. Sci. Technol. 2017; 27: 3-7.

4. Shadrin A. V. Static and dynamic outburst hazard of coal seams. Bezopasnost truda v promyshlennosti $=$ Occupational Safety in Industry. 2018; 4: 42-48. (In Russ.)

5. Fisenko G. L. Limit state of rock around mine workings. Moscow: Nedra Publishing; 1976. (In Russ.)

6. Napier J. A. L., Malan D. Simulation of tabular mine face advance rates using a simplified fracture zone model. Int. J. Rock Mech. Min. Sci. 2018; 109: 105-114.

7. Guo H., Yuan L. An integrated approach to study of strata behaviour and gas flow dynamics and its application. International Journal of Coal Science \& Technology. 2015; 2 (1): 12-21.

8. Guo W., Xu F. Numerical simulation of overburden and surface movements for Wongawilli strip pillar mining. Int. J. Min. Sci. Technol. 2016; 26: 71-76.

9. Khristianovich S. A. Continuum mechanics. Moscow: Nauka Publishing; 1981. (In Russ.)

10. Ruppeneit K. V. Some issues of rock mechanics. Moscow: Ugletekhizdat; 1954. (In Russ.)

11. Gao W. Study on the width of the non-elastic zone in inclined coal pillar for strip mining. Int. J. Rock Mech. Min. Sci. 2014; 72: 304-310.

12. Sokolovskii V. V. Granular materials statics. Moscow: Nauka Publishing; 1990. 272 c.

13. Cherdantsev N. V., Cherdantsev S. V. The analysis of the state of a coal mass with an in-seam working and fracture. Izvestiia RAN. Mekhanika tverdogo tela = Mechanics of Solids. 2018; 2: 110-121. (In Russ.)

14. Cherdantsev N. V. Solution to the problem of soil rock layer heaving in the in-coal working. Izvestiya vysshikh uchebnykh zavedenii. Gornyi zhurnal = News of the Higher Institutions. Mining Journal . 2016; 8: 32-39. (In Russ.)

15. Cherdantsev N. V. Solving a problem on ejection of a dirt seam from the coal seam floor in the in-seam working. Gornyi informatsionno-analiticheskii biulleten (nauchno-tekhnicheskii zhurnal) = Mining Informational and Analytical Bulletin (scientific and technical journal). 2017; 5: 369-381. (In Russ.)

16. Klishin V. I., Klishin S. V. Mineral mining technology: Coal extraction from thick flat and steep seams. Fiziko-tekhnicheskie problemy razrabotki poleznykh iskopaemykh = Journal of Mining Science. 2010; 2: 69-81. (In Russ.)

Received 16 May 2019

\section{Information about authors:}

Nikolai V. Cherdantsev - DSc (Engineering), leading researcher, Laboratory of Geomechanics and Geometrisation of Coal Fields, Federal Research Center of Coal and Coal Chemistry SB RAS. E-mail: nvch2014@yandex.ru 


\section{Построение решения задачи о состоянии угольного пласта методами механики сыпучей среды}

Черданцев Н. В. ${ }^{1}$

1 Федеральный исследовательский центр угля и углехимии Сибирского отделения РАН, Кемерово, Россия.

Peферат
Введение. Для обеспечения ритмичности и безопасности ведения горных работ необходимы надежные прогнозные оценки геомеханического состояния приконтурных зон отрабатываемого угольного пласта.

Цель работы. Построение модели состояния угольного пласта в его краевой зоне на основе фундаментальных методов механики сыпучих сред, проведение в ее рамках вычислений, анализ полученных результатов и их сравнение с результатами, полученными известными методами.

Методология. Задача о напряженном состоянии краевых зон угольного пласта реализуется путем численного решения трех краевых задач теории предельного равновесия для ряда характерных областей, расположенных в этих зонах. Критерием наступления предельного состояния является одновременное соблюдение условий Кулона-Мора по пласту и Мора-Кузнецова по его контакту с боковыми породами.

Результаты. Показано, что компоненты поля напряжений изменяются вдоль кровли пласта немонотонно. Участки, на которых напряжения постоянны, сменяются участками нелинейного их возрастания, и по мере удаления от краевой части в глубь массива размеры участков с постоянными напряжениями уменьшаются. Приведены сравнительные очзенки полученных результатов напряжений с результатами, полученными с использованием экспоненциальной формуль изменения напряжений. Установлены размеры приконтурной зоны пласта, в которых результаты по двум подходам достаточно близки друг другу.

Выводы. Аппроксимация полученных графиков полиномами позволяет с высокой степенью точности заменить результаты численного решения задачи предельного состояния аналитическими функциями и упростить решение задачи о напряженном состоянии вмещающего массива.

Ключевые слова: массив горных пород; угольный пласт; горная выработка; предельно напряженные зоны пласта; критерии прочности Кулона-Мора и Мора-Кузнецова.

\section{БИБЛИОГРАФИЧЕСКИЙ СПИСОК}

1. Петухов И. М., Линьков А. М. Механика горных ударов и выбросов. М.: Недра, 1983. 280 с.

2. Чернов О. И., Пузырев В. Н. Прогноз внезапных выбросов угля и газа. М.: Недра, 1979. 296 с.

3. Zhang C., Canbulat I., Tahmasebinia F., Hebblewhite B. Assement of energy release mechanisms contributing to coal burst // Int. J. Rock Min. Sci. Technol. 2017. No. 27. P. 3-7.

4. Шадрин А. В. Статическая и динамическая выбросоопасность угольных пластов // Безопасность труда в промышленности. 2018. № 4. С. 42-48.

5. Фисенко Г. Л. Предельные состояния горных пород вокруг выработок. М.: Недра, 1976. 272 с.

6. Napier J. A. L., Malan D. Simulation of tabular mine face advance rates using a simplified fracture zone model // Int. J. Rock Mech. Min. Sci. 2018. No. 109. P. 105-114.

7. Guo H., Yuan L. An integrated approach to study of strata behaviour and gas flow dynamics and its application // International Journal of Coal Science \& Technology. 2015. No. 2 (1). P. 12-21.

8. Guo W., Xu F. Numerical simulation of overburden and surface movements for Wongawilli strip pillar mining // Int. J. Min. Sci. Technol. 2016. No. 26. P. 71-76.

9. Христианович С. А. Механика сплошной среды. М.: Наука, 1981. 484 с.

10. Руппенейт К. В. Некоторые вопросы механики горных пород. М.: Углетехиздат, 1954. 384 с.

11. Gao W. Study on the width of the non-elastic zone in inclined coal pillar for strip mining // Int. J. Rock Mech. Min. Sci. 2014. No. 72. P. 304-310.

12. Соколовский В. В. Статика сыпучей среды. М.: Наука, 1990. 272 с.

13. Черданцев Н. В., Черданцев С. В. Анализ состояния углепородного массива, вмещающего пластовую выработку и геологическое нарушение // Известия РАН. Механика твердого тела. 2018. № 2. C. $110-121$.

14. Черданцев Н. В. Решение задачи о пучении породного слоя почвы выработки, пройденной по угольному пласту // Известия вузов. Горный журнал. 2016. № 8. С. 32-39.

15. Черданцев Н. В. Построение решения задачи о выпирании в пластовую выработку породного слоя, расположенного в почве угольного пласта // ГИАБ. 2017. № 5. С. 369-381.

16. Клишин В. И., Клишин С. В. Исследование процессов выпуска угля при отработке мощных пологих и крутых угольных пластов // Физико-технические проблемы разработки полезных ископаемых. 2010. № 2. С. 69-81. 


\section{Сведения об авторах:}

Черданцев Николай Васильевич - доктор технических наук, главный научный сотрудник лаборатории геомеханики и геометризации угольных месторождений Федерального исследовательского центра угля и углехимии Сибирского отделения РАН. E-mail: nvch2014@yandex.ru

Для цитирования: Черданцев Н. В. Построение решения задачи о состоянии угольного пласта методами механики сыпучей среды // Известия вузов. Горный журнал. 2019. № 7. С. 68-76 (In Eng.). DOI: 10.21440/0536-1028-2019-7-68-76

For citation: Cherdantsev N. V. Framing the solution to the problem of coal seam state by the methods of the mechanics of granular materials. Izvestiya vysshikh uchebnykh zavedenii. Gornyi zhurnal $=$ News of the Higher Institutions. Mining Journal. 2019; 7: 68-76. DOI: 10.21440/0536-1028-2019-7-68-76 